\title{
The Effects of Camellia sinensis Extract on Proliferation, Apoptosis and Oxidative Stress in Insulinoma INS-1 Cells
}

\author{
(D) Ayşe Karatuğ KAÇAR ${ }^{1}$, iD Melike ERSÖZ², iD Işıl SEZEKLER³, (D) Zeynep Mine COŞKUN²
}

1'stanbul University, Faculty of Science, Department of Biology, Istanbul, Turkey

2Demiroğlu Bilim University, Faculty of Arts and Sciences, Department of Molecular Biology and Genetics, İstanbul, Turkey

${ }_{3}$ Marmara University, Faculty of Science, Department of Biology, İstanbul, Turkey

\begin{abstract}
Objective: Green tea (Camellia sinensis) is one of the most consumed beverages in the world. C. sinensis consumption may prevent tumor and other diseases. Insulinomas are pancreatic islet cell tumors. In present study, the effects of the extract from $C$. sinensis were investigated in rat insulinoma INS-1 cells.

Methods: C. sinensis leaves were collected in Rize, Turkey. The leaves were brewed in tap water for 20 and 40 minutes at $80^{\circ} \mathrm{C}$. INS-1 cells were treated with different doses $(1-5 \mathrm{mg} / \mathrm{mL})$ of $C$. sinensis extract for $24 \mathrm{~h}$. Cell viability, proliferation, death were examined. The malondialdehyde, glutathione and protein carbonyl levels were measured in INS-1 cells given $C$. sinensis extract.

Results: The cell viability and the percentage of proliferating cell nuclear antigen immunopositive cells decreased, while the percentage of TUNEL positive cells increased in INS-1 cells treated with the extract from C. sinensis according to control group. While malondialdehyde and protein carbonyl levels in INS-1 cells treated with $C$. sinensis extract decreased, glutathione levels increased according to control group.

Conclusion: The results indicate that the extracts from $C$. sinensis inhibited proliferation and caused apoptosis in INS- 1 cell. C. sinensis may be natural agent for supporting the treatment of pancreatic tumors.
\end{abstract}

Keywords: Camellia sinensis extract, proliferation, apoptosis, oxidative stress, INS-1 cells

\section{Introduction}

The use of primary beta cells in biochemistry and molecular investigations is limited due to difficulty in obtaining pancreatic endocrine tissue. For this reason, many investigators prefer to study insulin-releasing cell lines, which maintain normal insulin secretion. The most commonly used insulin-releasing cell lines are RIN, HIT, beta TC, MIN6 and INS-1 cells (1). MIN6 and INS-1 cells reflect the physiological situation of beta cells in the best way when stimulated by glucose (2). Although the behavior of these cell lines does not exactly mimic the physiology of the primary beta cells, it is highly valuable for studying the molecular events underlying beta cell function and dysfunction (1). INS-1 exhibits several important characteristics of pancreatic beta cells (2).

There are various types of herbal teas including black and green tea. Green tea (Camellia sinensis) is one of the most consumed beverages in the world. People living in different regions have a variety of ways to brew tea $(3,4)$. The previous studies with different brands of tea demonstrated that brewing time is important to increase its antioxidant capacity, total phenolic and catechin content (5). Furthermore, the protective effects of $C$. sinensis were demonstrated in different types of cancers such as breast, ovarian, prostate and pancreatic cancers. The importance of anti-cancer activity of tea was highlighted (6-9)
Address for Correspondence: Ayşe Karatuğ KAÇAR, Istanbul University, Faculty of Science, Department of Biology, Istanbul, Turkey

Phone: +90 2124555700 E-mail: akaratug@istanbul.edu.tr ORCID ID: orcid.org/0000-0001-6032-470X
Received: 14.12.2017

Accepted: 02.04.2018

Cite this article as: Kaçar A, Ersöz M, Sezekler I, Coşkun ZM. The Effects of Camellia sinensis Extract on Proliferation, Apoptosis and Oxidative Stress in Insulinoma INS-1 Cells. Bezmialem Science 2019;7(2):80-5.

${ }^{\circledR}$ Copyright 2019 by the Bezmiâlem Vakıf University

Bezmiâlem Science published by Galenos Publishing House. 
In the current study, the effects of the extract from C. sinensis on cytotoxicity, proliferation, apoptosis and oxidative stress status were investigated in rat insulinoma INS-1 cells.

\section{Methods}

\section{Extraction of $C$. sinensis}

C. sinensis leaves were collected in Rize, Turkey as first harvest in May the leaves were dried, and a classic brewing method was applied to the green tea leaves to prepare the extract. The water used as solvent. Two hundred fifty $\mathrm{mL}$ water was used for the brew of $5 \mathrm{~g}$ of $C$. sinensis leaves. The dried leaves were brewed in tap water for 20,40 and 60 minutes at $80^{\circ} \mathrm{C}$ and extracts were obtained. And then, the extracts were cooled at room temperature, and the supernatants were removed after centrifugation at $4000 \mathrm{~g}$ for 15 minutes. So, the extract was obtained from C. sinensis. In vitro study was not approved.

\section{Cell Culture}

Insulinoma INS-1 cell line was a generous gift from Prof. Dr. Claes B. Wollheim (University Medical Center, Geneva). INS-1 cells were cultured in a humidified atmosphere containing 5\% $\mathrm{CO}_{2} / 95 \%$ humidified air at $37^{\circ} \mathrm{C}$ in Roswell Park Memorial Institute (RPMI) 1640 (Invitrogen) containing $10 \mathrm{mM}$ HEPES (Sigma), $50 \mathrm{mM}$ 2-mercaptoethanol (Biorad), $1 \mu \mathrm{M}$ sodium pyruvate (Sigma), 5\% fetal bovine serum (Gibco), $100 \mathrm{IU} / \mathrm{mL}$ penicillin and $100 \mu \mathrm{g} / \mathrm{mL}$ streptomycin (Gibco).

The INS-1 cells which were treated with brewed $C$. sinensis leaves in water for 20, 40 and 60 minutes were named as group I, II and III, respectively. Also, the untreated INS-1 cells were named as control group.

\section{Cell Viability Assay}

The effects on cell viability of $C$. sinensis extract determined by using 3-(4.5-dimethylthiazol-2-yl)-2.5-diphenyltetrazolium bromide (MTT) $(0.5 \mathrm{mg} / \mathrm{mL})$ (Applichem). INS-1 cells were seeded, and different doses $(1-5 \mathrm{mg} / \mathrm{mL})$ of $C$. sinensis were applied to INS-1 cells for 24 hours. The final concentration of the C. sinensis extract was $1-5 \mathrm{mg} / \mathrm{mL}$. After that, MTT was added and incubated for 2 hours. The medium was removed from cells and isopropanol was added to solve formazan (10). Absorbance values were measured at $540 \mathrm{~nm}$. Cell viability \% rate was calculated. IC50 value of C. sinensis was $4.535 \mathrm{mg} / \mathrm{mL}$ for group I, 4,121 mg/mL for group II, $4.041 \mathrm{mg} / \mathrm{mL}$ for group III.

\section{Cell Proliferation Assay}

Cell proliferation assay was performed by PCNA immune marking. On 24-well plates, $25 \times 10^{4}$ cells/well were seeded and grown on coverslip. Then it was incubated in $5 \% \mathrm{CO}_{2} / 95 \%$ humidified air at $37^{\circ} \mathrm{C}$ until the cells proliferated. Three and 4 $\mathrm{mg} / \mathrm{mL}$ final concentration of $C$. sinensis extract were applied to the cells for 24 hours. The cells were washed with phosphate buffered saline (PBS), and fixed with methanol for 5 minimum $(\min )$ at $-20^{\circ} \mathrm{C}$. The cells were incubated with blocking solution for $20 \mathrm{~min}$ at room temperature to avoid non-specific immunostaining. PCNA antibody (Neomarkers, USA; dilution $1: 300$, overnight at $4^{\circ} \mathrm{C}$ ) was used for immunocytochemical labeling by streptavidin-biotin-peroxidase technique in INS-1 cells. After that, the cells were washed with PBS, and biotinylated secondary antibodies and streptavidin, biotinylated horseradish peroxidase (Invitrogen, USA) were applied to INS-1 cells. AEC (Invitrogen, USA) was used to reveal immunopositive cells. The cells were mounted in glycerin gelatin and preserved at $4^{\circ} \mathrm{C}$ until microscopic examination. The percentage of immunopositive cells were calculated according to following formulas: (The number of immunpositive cells /total cells) x 100 .

\section{Cell Death Assay}

Cell death assay was determined with TUNEL method by using the In situ Cell Death Detection Kit (Millipore, USA). On 24-well plates, $25 \times 10^{4}$ cells/wells were seeded and grown on coverslip. Then it was incubated in $5 \% \mathrm{CO}_{2} / 95 \%$ humidified air at $37^{\circ} \mathrm{C}$ until the cells proliferated. Three and $4 \mathrm{mg} / \mathrm{mL}$ final concentrations of $C$. sinensis extract were applied to the cells for 24 hours. Then the cells were treated with equilibration buffer for 2 min at room temperature. Terminal deoxynucleotidyl transferase (TdT) enzyme and reaction buffer were mixed. It was treated for 1 hour at $37^{\circ} \mathrm{C}$. After that, the cells were incubated with the anti-digoxigenin conjugate for $30 \mathrm{~min}$ at room temperature. The diaminobenzidine was used to reveal immunopositive cells. The percentage of immunopositive cells was calculated according to the following formulas: (The number of apoptotic cells / total cells) x 100 .

\section{Glutathione, Protein Carbonyl and Malondialdehyde Assay}

On 6-well plates, $10^{6}$ cells/wells were seeded and incubated in $5 \% \mathrm{CO}_{2} / 95 \%$ humidified air at $37^{\circ} \mathrm{C}$ for determination of biochemical analysis. After incubation, $0.25 \%$ tripsin-EDTA was added the cells. It was removed and centrifuged at 1500 rpm for 5 minutes. Lysis buffer (Cell Signaling) was added on pellet. The cells were kept on ice for 5 minutes, and sonicated with ultrasonic water bath. They were centrifuged at $14000 \mathrm{~g}$ for 10 minutes. Supernatants were collected and the levels of malondialdehyde (MDA), glutathione (GSH), protein carbonyl (PCO), and protein content were measured by Ledwozyw's (11), Beutler's (12), Reznick and Packer's (13), and Lowry's methods (14), respectively.

\section{Statistical Analysis}

The image was captured using an Olympus BX - 50 microscope. Minimum 10 fields were selected randomly and immunopositive cells were counted in each field. Microscopic results were analyzed using One-Way variance (ANOVA), followed by Tukey's multiple comparisons test by using GraphPad Prism version 5.0 computer package for immunohistochemistry. Biochemical results carried out using SPSS software (SPSS, version 21.0). The statistical analysis was performed for statistical significance using ANOVA, followed by Tukey's post-hoc test. A $\mathrm{p}<0.05$ was considered significant. 


\section{Results}

The Cell Viability \% of INS-1 Cells Decreased with Camellia sinensis Extract

We determined cell viability percentage of INS-1 cells treated with the extract obtained from $C$. sinensis by MTT assay. INS-1 cells were treated with $1-5 \mathrm{mg} / \mathrm{mL}$ extract for 3 groups. For group I, the cell viability $\%$ significantly decreased in INS-1 cells given C. sinensis extract at $3 \mathrm{mg} / \mathrm{mL}(\mathrm{p}<0.05), 4 \mathrm{mg} / \mathrm{mL}(\mathrm{p}<0.001)$ and $5 \mathrm{mg} / \mathrm{mL}(\mathrm{p}<0.0001)$ concentrations compared with the control group. The cell viability $\%$ significantly decreased in the group II at $3 \mathrm{mg} / \mathrm{mL}(\mathrm{p}<0.001), 4 \mathrm{mg} / \mathrm{mL}(\mathrm{p}<0.0001)$ and $5 \mathrm{mg} / \mathrm{mL}(\mathrm{p}<0.0001)$ concentrations of the $C$. sinensis extract compared with the control group. Similarly, for group III, the cell viability \% significantly decreased in INS-1 cells given 2 $\mathrm{mg} / \mathrm{mL}$ ( $\mathrm{p}<0.001), 3 \mathrm{mg} / \mathrm{mL}$ ( $\mathrm{p}<0.0001), 4 \mathrm{mg} / \mathrm{mL}$ ( $\mathrm{p}<0.0001)$ and $5 \mathrm{mg} / \mathrm{mL}(\mathrm{p}<0.0001)$ concentrations of $C$. sinensis extract compared with the control group (Figure 1). The results of group II and III were similar for $3 \mathrm{mg} / \mathrm{mL}, 4 \mathrm{mg} / \mathrm{mL}$ and $5 \mathrm{mg} / \mathrm{mL}$ doses of extract. Therefore, we studied group I and II brewing $C$. sinensis leaves in tap water for 20 and 40 minutes, respectively in later experiment.

\section{INS-1 Cell Proliferation was Inhibited by Given $C$. sinensis Extract}

PCNA antibody was examined as a proliferation marker. The percentage of PCNA immunopositive cells significantly decreased in group I at both $3 \mathrm{mg} / \mathrm{mL}$ and $4 \mathrm{mg} / \mathrm{mL}$ concentrations of the extract, as well as group II given $4 \mathrm{mg} / \mathrm{mL}$ extract from $C$. sinensis compared with the control group $(\mathrm{p}<0.001, \mathrm{p}<0.05$, and $\mathrm{p}<0.001$, respectively). Besides, PCNA immunopositive cells significantly decreased in group II given $4 \mathrm{mg} / \mathrm{mL}$ extract from C. sinensis compared with the group II given $3 \mathrm{mg} / \mathrm{mL}$ extract $(\mathrm{p}<0.05)$ (Figure 2).

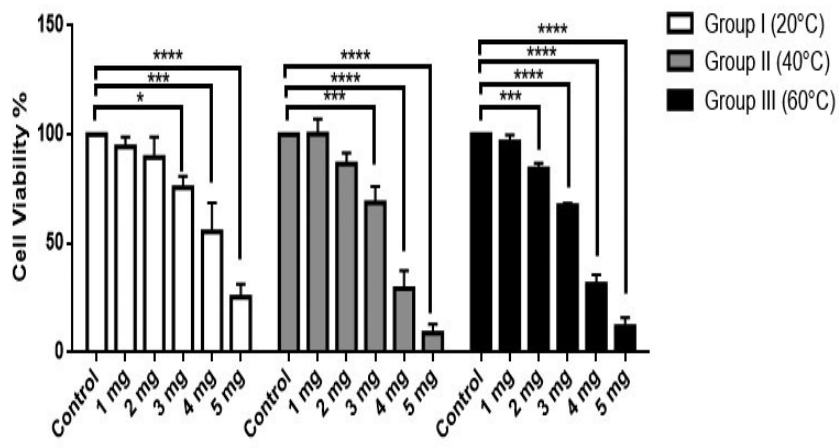

Figure 1. The cell viability \% in INS-1 cells with Camellia sinensis extract. ${ }^{*} p<0.05,{ }^{* * *} p<0.001,{ }^{* * * *} p<0.0001$
The Number of Apoptotic Cells Increased after Treating INS1 Cells with $C$. sinensis Extract

TUNEL method was examined for the cell death detection. The percentage of TUNEL positive cells increased in group II given 4 $\mathrm{mg} / \mathrm{mL}$ extract from $C$. sinensis compared with the control group ( $\mathrm{p}<0.001)$. Besides, TUNEL positive cells increased in group II given $4 \mathrm{mg} / \mathrm{mL}$ extract from $C$. sinensis compared with group II given $3 \mathrm{mg} / \mathrm{mL}$ extract from C. sinensis ( $<<0.01$ ) (Figure 3 ).

Glutathione, Protein Carbonyl and Malondialdehyde Levels Significantly Changed in INS-1 Cells Given C. sinensis Extract

GSH levels showed a significantly increase in group I given 3 and $4 \mathrm{mg} / \mathrm{mL}$ extract from C. sinensis compared with the control group $(\mathrm{p}<0.001$ and $\mathrm{p}<0.001)$. GSH levels increased in group II given $3 \mathrm{mg} / \mathrm{mL}$ extract from $C$. sinensis compared with the control group $(\mathrm{p}<0.001)$, while GSH levels in group II given $4 \mathrm{mg} / \mathrm{mL}$ extract from $C$. sinensis were lower than both control group $(\mathrm{p}<0.001)$ and group I given $3 \mathrm{mg} / \mathrm{mL}$ extract from $C$. sinensis $(\mathrm{p}<0.001)$ (Table 1$)$.

PCO levels significantly increased in group I given $3 \mathrm{mg} / \mathrm{mL}$ extract from C. sinensis $(\mathrm{p}<0.001)$, while PCO levels decreased in group I given $4 \mathrm{mg} / \mathrm{mL}$ extract from $C$. sinensis compared with the control group $(\mathrm{p}<0.001)$. Besides, PCO levels decreased in group II given both 3 and $4 \mathrm{mg} / \mathrm{mL}$ doses of $C$. sinensis extract compared with the control group $(\mathrm{p}<0.001$ and $\mathrm{p}<0.001)$ (Table $1)$.
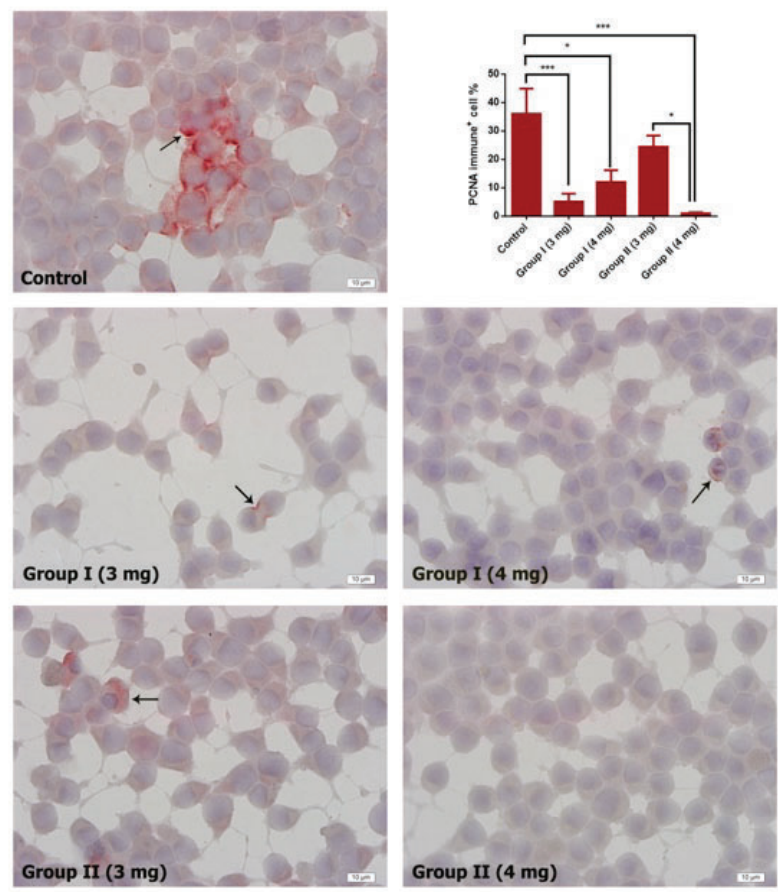

Figure 2. Proliferating cell nuclear antigen immunopositive cell number \% in INS-1 cells with Camellia sinensis extract. ò: Proliferating cell nuclear antigen immunopositive cells, ${ }^{*} p<0.05,{ }^{* *} p<0.001$ 
Table 1. Glutathione, protein carbonyl, and malondialdehyde levels in INS-1 cells with Camellia sinensis extract

\begin{tabular}{|c|c|c|c|c|c|c|}
\hline & \multicolumn{2}{|l|}{ GSH } & \multicolumn{2}{|l|}{ PCO } & \multicolumn{2}{|l|}{ MDA } \\
\hline & $3 \mathrm{mg} / \mathrm{mL}$ & $4 \mathrm{mg} / \mathrm{mL}$ & $3 \mathrm{mg} / \mathrm{mL}$ & $4 \mathrm{mg} / \mathrm{mL}$ & $3 \mathrm{mg} / \mathrm{mL}$ & 4 mg/mL \\
\hline Control & $5.43 \pm 0.00$ & $5.43 \pm 0.00$ & $1.94 \pm 0.00$ & $1.94 \pm 0.00$ & $2.33 \pm 0.05$ & $2.33 \pm 0.05$ \\
\hline Group I & $6.25 \pm 0.00^{\mathrm{a}}$ & $5.95 \pm 0.05^{\mathrm{a}}$ & $2.86 \pm 0.05^{\mathrm{a}}$ & $1.79 \pm 0.00^{\mathrm{a}}$ & $1.46 \pm 0.00^{\mathrm{a}}$ & $1.01 \pm 0.00^{\mathrm{a}}$ \\
\hline Group II & $7.89 \pm 0.05^{\mathrm{a}, \mathrm{b}}$ & $4.69 \pm 0.00^{\mathrm{a}, \mathrm{b}}$ & $0.95 \pm 0.00^{\mathrm{a}, \mathrm{b}}$ & $1.72 \pm 0.00^{\mathrm{a}, \mathrm{b}}$ & $1.88 \pm 0.00^{\mathrm{a}, \mathrm{b}}$ & $1.98 \pm 0.00^{\mathrm{a}, \mathrm{b}}$ \\
\hline$P_{\text {ANOVA }}$ & $<0.001$ & $<0.001$ & $<0.001$ & $<0.001$ & $<0.001$ & $<0.001$ \\
\hline
\end{tabular}

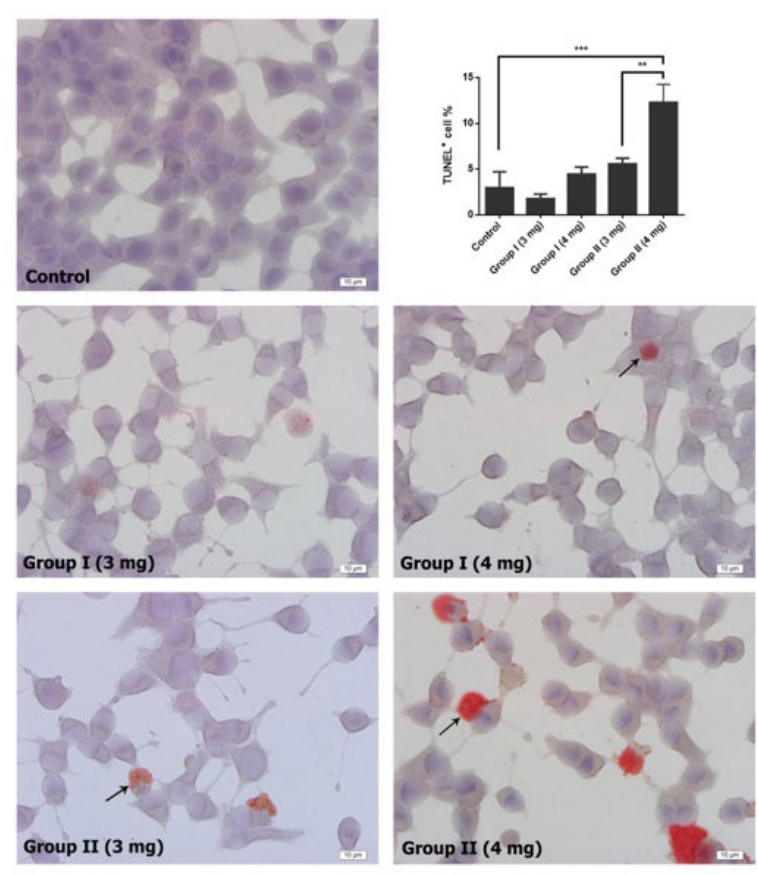

Figure 3. TUNEL positive cell number \% in INS-1 cells with Camellia sinensis extract. Ò : TUNEL immunopositive cells, ${ }^{* *} \mathrm{p}<0.01, * * * \mathrm{p}<0.001$

MDA levels showed a significant decrease in both group I and II given $3 \mathrm{mg} / \mathrm{mL}$ and $4 \mathrm{mg} / \mathrm{mL}$ concentration of $C$. sinensis extract compared with the control group $(\mathrm{p}<0.001$ and $\mathrm{p}<0.001)$. Furthermore, MDA levels were higher in group II given $4 \mathrm{mg} /$ $\mathrm{mL}$ extract from C. sinensis compared with group II given $3 \mathrm{mg} /$ $\mathrm{mL}$ extract $(\mathrm{p}<0.001)$ (Table 1$)$.

\section{Discussion}

Green tea (C. sinensis) is widely use in the world. There are phytochemicals and functional components in this species of tea. These components have significant benefits on human health. Therefore, consumption of tea at effective levels is important (15). C. sinensis contains polyphenols which are related with antioxidant activity. Brewed green tea contains high levels of catechins (16). Catechin levels are important factors indicating the quality of the tea (17). Catechins and caffeine were shown in green tea in several studies (18-20). There are five catechins including catechin, (2)-epicatechin, (2)-epicatechin gallate, (2)-epigallocatechin and (2)-epigallocatechin gallate. Different types of tea may have different caffeine and catechin contents (21). Oxidative damage can be cured with phytochemicals found in tea in diseases such as cancer $(15,22)$. Healing properties of $C$. sinensis have been investigated in many types of cancers such as metastatic breast (6), human ovarian (7), lung (23), and prostate cancers (8). The effects of $C$. sinensis were investigated in pancreatic carcinoma cells $(9,24)$. However, there is no investigation of cell viability in insulinoma INS-1 cells. We applied extract of $C$. sinensis at different doses $(1-5 \mathrm{mg} / \mathrm{mL})$ and brewing times (20, 40 and 60 minutes) at $80^{\circ} \mathrm{C}$ to the cells to investigate killing effect of $C$. sinensis in insulinoma INS-1 cells. The brewing time is important to increase the antioxidant capacity. Therefore, we continued to study with groups I (20 minutes) and II (40 minutes), due to similar results in groups II and III (60 minutes). Furthermore, $3 \mathrm{mg} / \mathrm{mL}$ and $4 \mathrm{mg} / \mathrm{mL}$ concentration of the extract were considered as effective doses in these groups.

In a previous study, the authors showed that green tea inhibited proliferation and also induced apoptosis in 4TI metastatic breast cancer cells (6) and in A549 lung carcinoma cells (23). These effects have not been determined in insulinoma INS-1 cell line. Our results indicated that extract from $C$. sinensis inhibited proliferation, and caused apoptosis in insulinoma INS-1 cell. It was observed that the increase of brewing time changed cell proliferation and death. The increase in brewing time reduced the cell proliferation, and elevated apoptosis in INS-1 cells.

The authors have shown in a study that green tea can regulate the antioxidant capacity in people exposed to oxidative stress (25). Besides, C. sinensis decreased oxidative stress in patients with prostate cancer (26). In a study, it was suggested that green tea showed protective effects through its antioxidant properties against oxidative stress and DNA damages, (27). Furthermore, 
antioxidant capacity in $C$. sinensis was increased depending on the duration of brewing. Our data showed a decrease in the levels of MDA and PCO that are known as markers of oxidative stress in insulinoma INS-1 cells treated with extract of $C$. sinensis. Besides, glutathione is an important antioxidant and protects cells against oxidative stress. According to our results, extract of C. sinensis increased the glutathione levels. We hypothesized that C. sinensis has a positive protective effect on insulinoma cells.

Our aim was to prevent the proliferation of tumor cells and to induce cell death. We observed both inhibition of cell proliferation, and increase in apoptotic cells. We have also shown that the oxidative stress may cause decreased MDA, PCO levels and increased GSH levels in insulinoma cells. So, we can say that $C$. sinensis may be natural agent to support the treatment of various carcinomas.

\section{Acknowledgements}

Thank to Prof. Dr. Claes B. Wollheim (University Medical Center, Geneva) for providing kind gift of insulinoma INS-1 cell lines.

Ethics Committee Approval: In vitro study was not approved.

Informed Consent: In vitro study was not approved.

Peer-review: Externally and internally peer-reviewed.

\section{Authorship Contributions}

Concept: A.K.K., M.E., I.S., Z.M.C., Design: M.E., Z.M.C., Data Collection or Processing: M.E., Z.M.C., Analysis or Interpretation: A.K.K., M.E., I.S., Z.M.C., Literature Search: A.K.K., I.S., Writing: A.K.K.

Conflict of Interest: No conflict of interest was declared by the authors.

Financial Disclosure: The authors declared that this study received no financial support.

\section{References}

1. Poitout V, Olson LK, Robertson RP. Insulin secreting cell lines: classification, characteristics and potential applications. Diabetes Metab 1996;22:7-14.

2. Skelin M, Rupnik M, Cencic A. Pancreatic beta cell lines and their applications in diabetes mellitus research. Altex 2010;27:105-13.

3. Lian G, Astill C. Computer simulation of the hydrodynamics of teabag infusion. Food and Bioproducts Processing 2002;80:155-62.

4. Soylak M, Tuzen M, Souza AS, das Graças Andrade Korn M, Ferreira SL. Optimization of microwave assisted digestion procedure for the determination of zinc, copper and nickel in tea samples employing flame atomic absorption spectrometry. J Hazard Mater 2007;149:264-8.

5. Kyle JAM, Morrice PC, Mcneill G, Duthie GG. Effects of Infusion Time and Addition of Milk on Content and Absorption of Polyphenols from Black Tea. J Agric Food Chem 2007;55:4889-94.
6. Mbuthia KS, Mireji PO, Ngure RM, Stomeo F, Kyallo M, Muoki $\mathrm{C}$, et al. Tea (Camellia sinensis) infusions ameliorate cancer in 4TI metastatic breast cancer model. BMC Complement Altern Med 2017;17:202.

7. Jia LY, Wu XJ, Gao Y, Rankin GO, Pigliacampi A, Bucur H, et al. Inhibitory Effects of Total Triterpenoid Saponins Isolated from the Seeds of the Tea Plant (Camellia sinensis) on Human Ovarian Cancer Cells. Molecules 2018;23. pii: E1469.

8. Lassed S, Deus CM, Djebbari R, Zama D, Oliveira PJ, Rizvanov AA, et al. Protective Effect of Green Tea (Camellia sinensis (L.) Kuntze) against Prostate Cancer: From In Vitro Data to Algerian Patients. Evid Based Complement Alternat Med 2017;2017:1691568.

9. Zhang L, Pang E, Loo RR, Rao J, Go VL, Loo JA, et al. Concomitant inhibition of HSP90, its mitochondrial localized homologue TRAP1 and HSP27 by green tea in pancreatic cancer HPAF-II cells. Proteomics 2011;11:4638-47.

10. Janjic D, Wollheim CB. Islet cell metabolism is reflected by the MTT (tetrazolium) colorimetric assay. Diabetologia 1992;35:482-5.

11. Ledwozyw A, Michalak J, Stepien A, Kadziolka A. The relationship plasma triglycerides, cholesterol, total lipids, and lipid peroxidation products during human atherosclerosis. Clin Chim Acta 1986;155:275-84.

12. Beutler E. Glutathione in red blood cell metabolism: a manual of biochemical method., 2 nd ed. Grune and Stratton (pp.112-114) New York 1975.

13. Reznick AZ, Packer L. Oxidative damage to proteins: spectrophotometric method for carbonyl assay. Methods Enzymol 1994;233:357-63.

14. Lowry OH, Rosebrough WI, Farr AL, Randal RJ. Protein measurement with the folin phenol reagent. J Biol Chem 1951;193:265-75.

15. Karori SM, Wachira FN, Ngure RM, Mireji PO. Polyphenolic composition and antioxidant activity of Kenyan Tea cultivars. Journal of Pharmacognosy and Phytochemistry 2014;3:105-16.

16. Hilton PJ, Ellis RT. Estimation of the market value of Central African tea by theaflavin analysis. J. Sci. Food Agric 1972;23:227-32.

17. Bronner WE, Beecher GR. Method for determining the content of catechins in tea infusions by high-performance liquid chromatography. J Chromatogr A 1998;805:137-42.

18. Horie $\mathrm{H}$ and Kohata K. Application of capillary electrophoresis to tea quality estimation. J Chromatogr A 1998;802:219-23.

19. Arce L, Ríos A, Valcárcel M. Determination of anti-carcinogenic polyphenols present in green tea using capillary electrophoresis coupled to a flow injection system. J. Chromatogr A 1998;827:11320.

20. Larger PJ, Jones AD, Dacombe D, Separation of tea polyphenols using micellar electrokinetic chromatography with diode array detection. J Chromatogr A 1998;799:309.

21. Fernández PL, Martín MJ, González AG, Pablos F. HPLC determination of catechins and caffeine in tea. Differentiation of green, black and instant teas. Analyst 2000;125:421-5.

22. Wachira FN, Kamunya SM. Kenyan Teas Are Rich In Antıoxıdants Tea 2005;26:81-9. 
23. Zhou L, Wu F, Jin W, Yan B, Chen X, He Y, et al. Theabrownin Inhibits Cell Cycle Progression and Tumor Growth of Lung Carcinoma through c-myc-Related Mechanism. Front Pharmacol 2017;8:75.

24. Lin Y, Kikuchi S, Tamakoshi A, Yagyu K, Obata Y, Kurosawa M, et al; JACC Study Group. Green tea consumption and the risk of pancreatic cancer in Japanese adults. Pancreas 2008;37:25-30.

25. Peluso I, Serafini M. Antioxidants from black and green tea: from dietary modulation of oxidative stress to pharmacological mechanisms. Br J Pharmacol 2017;74:1195-208.
26. Lassed S, Deus CM, Djebbari R, Zama D, Oliveira PJ, Rizvanov AA, et al. Protective Effect of Green Tea (Camellia sinensis (L.) Kuntze) against Prostate Cancer: From In Vitro Data to Algerian Patients. Evid Based Complement Alternat Med 2017;2017:1691568.

27. Barg M, Rezin GT, Leffa DD, Balbinot F, Gomes LM, CarvalhoSilva M, et al. Evaluation of the protective effect of Ilex paraguariensis and Camellia sinensis extracts on the prevention of oxidative damage caused by ultraviolet radiation. Environ Toxicol Pharmacol 2014;37:195-201. 